\title{
A sociabilidade em ondas sonoras: as audiências e o rádio dos anos 50 e 60 em fortaleza
}

\author{
Roberta Manuela Barros de Andrade ${ }^{1}$ \\ Erotilde Honório Silva ${ }^{2}$
}

\begin{abstract}
Resumo: O presente estudo reflete sobre os significados das sociabilidades mediadas pelo rádio a partir de duas perspectivas distintas: a dos produtores do rádio nos anos cinqüenta e sessenta do século $X X$ e a de seus ouvintes no mesmo período, na cidade de Fortaleza, localizada na região Nordeste do Brasil. Este recorte temporal se apresenta como extremamente rico no que diz respeito às sociabilidades mediadas pelo rádio devido às radicais mudanças decorridas de um período histórico a outro, marcadas pela eclosão do regime de exceção no País. Selecionamos para tal, vinte produtores e receptores daquelas décadas, hoje entre 60 e 80 anos de idade. A pergunta-chave que move este estudo é, pois, como o rádio pôde funcionar como meio construtor de novas sociabilidades para estes sujeitos históricos situados em topografias sociais distintas.
\end{abstract}

Palavras-chave: rádio, sociabilidades, audiências.

\begin{abstract}
The present study reflects on the meanings of the sociabilities mediated for the radio from two distinct perspectives: of the producers of the radio in the fifties and sixty of century $X X$ and of its listeners in the same period, in the city of Fortaleza, located in the Northeast region of Brazil. This period of time presents itself as extremely rich concerning the sociabilities mediated for the radio due to the radical changes which took place during the passing from a historical period to another one, marked for the eclosion of the regimen of exception in the Country. We selected for this study, twenty producers and receivers of those decades, today between 60 and 80 years of age. The main question that moves this study is, therefore, how the radio could function as a means constructor of new sociabilities for these historical citizens situated in distincted social topographies.
\end{abstract}

Key-words: radio, sociabilities, audience.

Resumén: El actual estudio reflexiona sobre los significados de las sociabilidades mediadas para el radio a partir de dos perspectivas distintas: de los productores del radio en los años 50 y 60 del siglo XX y de sus oyentes en el mismo período, en la ciudad de Fortaleza, situada en la región nordeste de Brasil. Este recortado temporal se presenta muy rico en lo que dice respecto a las sociabilidades mediadas para el radio debido a los cambios radicales de un período histórico a otro, marcados por el surgimiento del régimen de la excepción en el País. Seleccionamos para tal, veinte productores y los receptores de esas décadas, hoy entre 60 y 80 años de edad. La pregunta clave que mueve este estudio es, por lo tanto, como el radio podría funcionar como el medio constructor de nuevas sociabilidades para estos sujetos históricos situados en topografías sociales distintas.

Palabras-clave: radio, sociabilidad, audiencias.

Resumé: La présente étude reflète sur les significations des sociabilités négociées par la radio dans deux perspectives distinctes: ce des producteurs de la radio dans l'anées cinquante et soixante du XXe siècle et ce de leurs audiences dans la même période, dans la ville de Fortaleza, située en Nord-est du Brésil. Ce quadre de référence se présente comme extrêmement riche en ce qui concerne les sociabilités negociées par la radio dû aux radicaux changements passsés d'une période historique à autre, marquées par l'éclosion du régime d'exception dans le Pays. Nous sélectionons pour tel, vingt producteurs de cettes décennies, aujourd'hui entre soixante et vingtquatre ans d'âge. La interrogation première qui déplace cette étude est, donc, comment la radio a pu fonctionner comme constructeur de nouvelles sociabilités pour ces sujets historiques placés dans des topographies sociales divers.

Mot-clé: radio, sociabilités, audiences. 


\section{História, Sociabilidade e Cotidiano}

Uma das grandes questões que movem os estudos da mídia na atualidade diz respeito a reflexões sobre a inserção desta mídia no jogo social, em especial, no que se convencionou chamar de sociabilidades contemporâneas ${ }^{3}$. Entrementes, essa sociabilidade não é um todo homogêneo nem tampouco se revela da mesma forma para todos os agentes sociais de um dado período histórico. No que tange a esta pesquisa, escolhemos como objeto de estudo o rádio e como locus de reflexão as décadas de 50 e 60 do século passado no Nordeste do Brasil ${ }^{4}$. Tal recorde temporal é profícuo, pois, cremos, que este período se apresenta como extremamente rico no que diz respeito às sociabilidades mediadas pelo rádio devido às radicais mudanças decorridas de um período histórico a outro, marcadas pela eclosão do regime de exceção no País.

A importância de um estudo de tal ordem está não só na compreensão do rádio como uma mediação essencial para o entendimento dos ritos de interação que constituem uma dada época, mas também para o desvendamento de suas relações com as rotinas diárias, alicerçadas em categorias e construtos do senso comum ${ }^{5}$ de seus produtores e consumidores. Esta sociabilidade se funda, no que diz respeito a este trabalho, numa esfera envolvida pela ideologia desenvolvimentista de Juscelino Kubitschek dos anos 50 e que entra num processo de ruptura quando se instaura no Brasil a Ditadura Militar de 64. Neste sentido, a interação entre este contexto maior brasileiro e o contexto local de Fortaleza no qual as sociabilidades desses agentes sociais foram efetivamente instituídas são o nosso ponto de partida.

Enfatizamos, assim, o locus no qual essas interações se estabeleceram porque acreditamos como Parsons que as motivações dos atores sociais são integradas em modelos normativos, alicerçados em conjunturas que regulam as condutas e as apreciações recíprocas ${ }^{6}$. Neste sentido, os atores sociais, sujeitos desta pesquisa, compartilharam valores que não só os transcenderam, mas que também, governaram muitas de suas ações e interações ${ }^{7}$. Esse agir social está circunscrito a um cenário em comum que pode ser descrito a partir do imaginário sócio-político que circunscreveu a sociedade brasileira e fortalezense nas duas décadas selecionadas para este estudo.

Nessa perspectiva, a pergunta-chave que move este estudo é, pois: como o rádio mediou distintas sociabilidades para sujeitos pertencentes a um mesmo contexto histórico, mas, situados em topografias sociais diferenciadas. A partir desta indagação 
podemos perceber como o mesmo meio de comunicação propiciou sociabilidades diversas que se configuraram mediante a incorporação de um lugar social específico por parte de sujeitos sociais distintos.

Essas sociabilidades propiciadas pelo rádio fundaram negociações de sentido particulares para diferentes agentes sociais. Essas negociações de sentido, ressaltamos, respondem a um sistema de práticas e crenças que regulam âmbitos singulares da vida cotidiana $^{8}$ dessa comunidade imaginária, perfazendo interações sociais que só podem ser compreendidas se levarmos em consideração mudanças profundas ocorridas em três níveis diferentes: a) O contexto político da sociedade brasileira nos anos 50 e 60 do século passado; b) O contexto social de Fortaleza neste mesmo período; c) As diferentes sociabilidades configuradas pelo rádio em Fortaleza em duas épocas históricas tão próximas cronologicamente mas tão diversas simbolicamente.

Para materializarmos esta pesquisa, nos baseamos em depoimentos das comunidades interpretativas do rádio entre os anos 50 e 60. Selecionamos para tal, vinte

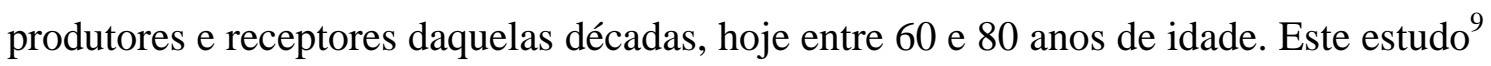
está, pois, ainda centrado nos mecanismos de construção de uma memória coletiva ${ }^{10}$ mediada pelos meios de comunicação de massa.

\section{Fortaleza: entre o provincianismo e a modernidade}

A partir do pós-guerra e durante toda a década de 50, consolida-se, em Fortaleza, como no resto do Brasil, a sociedade de consumo. Se na década anterior as camadas médias brasileiras ainda eram pouco numerosas e as atividades econômicas pouco diversificadas, nos anos 50, as cidades cresciam, dando nascimento a uma massa urbana com significativa força política, tornando a hierarquia das forças sociais mais complexas (Carone, 1980). Assim, em Fortaleza, o comércio estava vinculado a produtos como eletrodomésticos, cosméticos, veículos e confecção. A grande novidade da época foi a chegada do refrigerante. Surge também a facilidade de compra, o crediário, que insere parte significativa da população da classe média, dantes sem acesso a estes produtos, no consumo de bens e serviços.

O mercado publicitário cresce e os profissionais da área imprimem uma nova estética à propaganda seja para os meios impressos seja para os radiofônicos com os spots e jingles (Andrade e Silva, 2006). Neste período, cerca de 60\% do capital 
destinado à publicidade, pelas empresas, é aplicado no rádio na forma de publicidade e/ou de patrocínio de programas. O rádio torna-se o principal veículo de propaganda, configurando-se numa mídia que já atendia a uma segmentação de público.

A publicidade não era tão diferente do que é feito hoje. Claro que era uma coisa sem imagem. Era texto, agora com grandes locutores. Tinha a publicidade mais falada, mas se usava muito jingle. E muitos jingles daquele tempo até hoje são lembrados, como aquele do melhoral: Melhoral, Melhoral, é melhor e não faz mal”. (Karla Peixoto, 65, radioatriz).

A indústria local era acanhada e restringia-se ao refinamento de óleo, beneficiamento do algodão, da oiticica, produção de cigarros e a revenda de máquinas de costura. As empresas relacionadas ao setor de informação e entretenimento se destacavam como ícones da modernidade que finalmente chegavam à província. Eram estas as responsáveis pela transmissão de um imaginário que trazia à cultura local um fervilhar de idéias inovadoras mediadas pelo trabalho dos locutores, apresentadores, radioatores e radioatrizes, e, conformavam uma opinião pública que se nutria da credibilidade do novo meio.

Eu posso falar da Ceará Rádio Clube. Era uma emissora tão conceituada que se surgisse um boato na cidade que tá havendo um incêndio, que não sei quem matou não sei quem, as pessoas diziam "eu vou ouvir a PR-09 pra saber se é verdade" tal era a credibilidade que essa emissora tinha, e a influência na vida das pessoas (Glauria Faria,64, radioatriz).

As radionovelas anunciavam os produtos eletrodomésticos, os programas de auditório sorteavam brindes que variavam da colônia Aqua-velva aos óculos ray-ban, os humorísticos distribuíam o refrigerante Grapette e os radiojornais recebiam o patrocínio de grandes empresas. Os principais anunciantes eram lojas de departamentos, restaurantes, lanchonetes, farmácias e produtos alimentícios. Locutores, apresentadores, radioatores e radioatrizes, homens e mulheres vindos da classe média e em alguns poucos casos até das classes populares passavam de anônimos a pessoas de sucesso, reconhecidos, admirados e aclamados nos clubes, nos bares, nos bailes e na rua.

A fama dessas pessoas assemelhava-se aos atores e atrizes do cinema conhecidos apenas nas imagens das telas dos cinemas da cidade. Entrementes, a relação que se estabelecia entre ouvintes e fãs era bem diferenciada da que se vê na indústria cultural 
contemporânea, uma vez que a empolgação dos fãs não seguia o sucesso do momento, mas perdurava durante décadas.

Na verdade, uma coisa que eu acho muito importante nessa época, tanto do rádio como do princípio da televisão é que o artista era realmente consagrado pelo povo. Não era a mídia que fazia aquele ídolo pra depois derrubar, não era por aí, então quem se fazia ídolo era ídolo mesmo, os fãs ficavam velhinhos, o artista ficava velhinho e a relação continuava. (Glice Sales, 63, radioatriz).

Em contrapartida, em relação às pessoas que atuavam no rádio local, deles, os ouvintes, seus admiradores, se abastados, podiam estar próximos tanto nos programas de auditório como num convívio de um espaço social mais amplo, caracterizado por poucas opções de entretenimento e lazer, como nas festas e nos bailes dançantes e nos casos, dos menos favorecidos economicamente, nas ruas e nas lojas de departamento.

A gente podia encontrar os artistas locais nas ruas, nas lojas de departamento e até mesmo nos bailes dançantes. Não era aquele negócio de gente distante que a gente via nas revistas que tratavam dos artistas do Rio de Janeiro. (Neide Garcia, 62, professora aposentada.)

Apesar dos ideais modernistas, Fortaleza era uma cidade em processo desordenado de urbanização - o transporte público não atendia à demanda da população e as linhas de ônibus e bondes eram limitadas. A freqüência às praias ainda não se configurava como prática de lazer e entretenimento. Era uma opção de lazer destinada aos mais pobres que afastava as classes médias ao mesmo tempo em que o acesso aos clubes seletos e aos bailes dançantes com vitrolas ou orquestras era interditado à maioria.

As pessoas eram mais domésticas, não havia grandes atividades fora de casa. Praia ninguém freqüentava. (Diatahy Bezerra, 71, professor aposentado).

Grande parte da população ainda era analfabeta, morava em bairros de periferia, trabalhava em locais distantes desses bairros. A escola quando havia era precária e o atendimento à saúde também de difícil acesso. Os equipamentos culturais disponibilizados pelo Estado eram muito escassos e os existentes mal chegavam para a fruição das elites econômicas. Na política, imperava as oligarquias que realizavam alianças entre si e entre o poder religioso (Figueiredo, 1998; Singer, 1981). 
Em fins desta década, Fortaleza se encontra aturdida em conseqüência da seca de 58, quando as pensões acolhedoras de retirantes abarrotavam suas dependências já na expectativa da migração dos nordestinos agora não mais para o norte, à Amazônia, mas para a construção da nova capital do País, Brasília. Nas calçadas, as famílias se refrescavam, gastando o tempo com conversas de toda ordem. O concurso de Miss Ceará com vistas ao grande sonho de disputar o Miss Brasil povoava a cabeça das moças de todas as classes sociais e dominava as relações estabelecidas no cabeleireiro, na manicure, nas costureiras afamadas, nas lojas freqüentadas por quem detinha poder aquisitivo para produtos de luxo.

As investidas dos rabos-de-burro ${ }^{11}$ contra as indefesas mocinhas da Escola Normal e a construção da Concha Acústica na reitoria da Universidade Federal, a exuberância do Cinema São Luis, tanto tempo aguardado, tudo isso refletia a vontade do cearense de se enquadrar nos movimentos da modernidade, e era para lá, que a sociedade cearense se dirigia nas vesperais de domingo, no rigor da moda copiada de periódicos sulistas.

Na Rádio Dragão do Mar, a juventude ouvia os acordes da bossa nova. Os cearenses estavam mergulhados num clima contagiante de acesso à modernidade, aparentemente equiparando-se em “desenvolvimento” com os grandes centros do Brasil, desejo tão almejado pela comunidade provinciana alencarina ${ }^{13}$. Neste mesmo período, na sociedade mais global, o rádio revolucionava a vida brasileira e vivia ainda as glórias de sua ‘época de ouro’, passando a fazer parte do cotidiano dos ouvintes, consolidandose como o mais novo veículo de difusão da indústria cultural. No entanto, a fidelização ao rádio não era apenas direcionada pelas visões de mundo dos produtores dos centros mais avançados do País. Os contextos locais também influenciavam na forma como os ouvintes interagiam com o meio, como nos lembra Karla Peixoto:

As radionovelas tratavam em geral, era mais sobre amor, ódio, essas coisas que continuam alimentando o dia-a-dia da vida de todos nós. $O$ rádio influenciava no modo de falar, mas as pessoas só pensavam de acordo com o que tinham na mente pra visualizar, e isto tinha a ver com as próprias tradições de uma terra ainda provinciana. (Karla Peixoto, 65 , radioatriz).

Se o panorama que dava conta desta busca pela modernidade era nacional, os seus filtros eram profundamente locais. Desta forma, os noticiosos nacionais, 
retransmitidos em larga escala pelas redes locais traziam as esperanças de entrada das grandes capitais do Brasil, dentre elas Fortaleza, num mundo moderno, contagiante, cheio de possibilidades, muito próximo ao ideal de vida europeu e norte-americano. O lúdico aliado ao desejo de consumo de uma sociedade que se queria moderna formatavam a imagem de um País aparentemente em harmonia ${ }^{12}$.

Entrementes, o endurecimento do Regime Militar chega, obviamente, à Fortaleza. Ao sonho, ainda maior de desenvolvimento aqui encrustado porque ainda tão distante, se acopla os ventos da nova política de Brasília. À política oligárquica local, autoritária em seus princípios, mas cordial em sua aparência, se une a dureza da caserna, incompreensível para um povo que institui seu processo de dominação nas relações de compadrio (Buarque de Holanda, 1997). A “leveza” cearense que vaiava o sol na Praça do Ferreira, principal logradouro da Cidade, teve que se adaptar às ordens de agentes militares que, plenas de um autoritarismo "seco", entravam em choque com o apadrinhamento das forças políticas locais. Dissemina-se o medo e a desconfiança nas terras de José de Alencar.

\section{No ar: conservadorismo e transgressão nas sociabilidades alencarinas}

Na década de 50, o sentimento entre os membros da comunidade fortalezense de estarem “sociados”, pela mediação do rádio, pode ser compreendido a partir do fato dos produtores do rádio, de um lado, e os receptores do outro conviverem ambos no mesmo espaço social, compartilhando os aspectos da cultura local ${ }^{13}$. Esta cultura local estava alicerçada em valores provenientes de seu próprio processo histórico de configuração. Neste processo histórico, havia uma série de tabus e interditos sociais a que os produtores do rádio deveriam obedecer se quisessem criar uma fidelização em seus ouvintes. É o que demonstra o depoimento a seguir:

Veja bem, eram outros tempos, as próprias emissoras se autocensuravam porque elas sabiam que a sociedade não aceitava determinadas coisas. Então não adiantava você, por mais Rede Tupi que fosse, querer impor um padrão fora da moral social porque se a sociedade não aceitava, você tava ferrado, você tinha que fechar pra balanço. Então quem impunha as normas era a sociedade. (Karla Peixoto, 65, radioatriz). 
Esses processos societários nos quais se alocam as interações que os indivíduos estabelecem com a mídia encontram-se entrecruzados por numerosos círculos sociais que vão desde a esfera privada à esfera pública, passando pelos vários papéis que os indivíduos desempenham no todo social. Esses papéis encontram cenarizações diferenciadas tanto no mundo doméstico como no público. O rádio foi, pois, um elemento marcante no cotidiano dos indivíduos, excepcional elemento mediador de muitas de suas interações sociais, como demonstra o depoimento a seguir:

Pode-se dizer que o rádio era um cooperador da vida das pessoas. O rádio era uma coisa bem de família, era como uma forma de unir as pessoas. (Neide Garcia, 62, professora aposentada).

Entrementes, se as pessoas escutavam rádio, na Fortaleza dos anos 50, não se reuniam só para isso. A escuta atenta só acontecia no acompanhamento de programas especiais: as mulheres para o desenrolar de um episódio de sua novela favorita, os homens para escutarem os noticiosos mais interessantes.

A maioria das pessoas passava o dia escutando rádio, mas não se reuniam para isso. Abria ali, já ouvia, os que passavam ouviam, mas não se reunia para assistir, a não ser minha mãe e minha irmã que gostavam quando passou uma novela aqui chamada "Renúncia” e religiosamente, no horário da novela, me parece que era sete/oito horas da noite, estavam ali no pé do rádio para ouvir a "Renúncia”. (Nirez, 71, funcionário público).

A transmissão chegava aos rádios e era uma chiadeira, falava um pedaço e cortava outro. Mesmo assim, a gente ia a todas as casas com aqueles rádios velhos e horrorosos ligados na Hora do Brasil, porque os homens, os senhores, gostavam de saber as notícias da política. (Neide Garcia, 62, professora aposentada).

O sucesso do rádio era hegemônico. As pessoas continuavam, como em décadas anteriores a sentarem-se nas calçadas, mas quando seus programas preferidos as chamavam, elas largavam literalmente o batente, e entravam em seus lares para acompanhar o sucesso do mundo. Essa popularidade do rádio era mensurada pelas idas às emissoras, pelo envio de cartas, pelo uso de telefonemas, pelo reconhecimento de fãs nas ruas. Esta realidade é atestada pelos depoimentos a seguir:

Na época não tinha ibope mas dava pra se saber de seu sucesso através das cartas de ouvintes, das visitas dos ouvintes e dos telefonemas.(Ivone Meyre, 64, radioatriz). 
Aí quando eu falava numa loja, as pessoas mais argutas, de ouvido melhor, cochichavam com as outras e perguntavam: você trabalha na novela tal? Eu dizia: trabalho. Aí eles gritavam: fulano, vem ver!!! E falavam: - mas eu pensava que era uma meninazinha. Aí eu dizia: pois é, tá aqui, a criançona!! (Glice Sales, 63, radioatriz).

A repercussão da novela era de peso. Então aquilo ali era fácil de avaliar porque uma cidade de 300, 400 mil habitantes, de repente, onde as pessoas botavam cadeiras na calçada pra conversar, de repente as cadeiras sumiam, ia todo mundo pro pé do rádio ouvir a novela!! ( Karla Peixoto, 65, radioatriz)

Durante todo este período, em Fortaleza, a sociabilidade mediada pelo rádio tanto para ouvintes como produtores foi uma sociabilidade lúdica, no melhor sentido de Simmel (1983). Essa sociabilidade se revelava tanto nas fofocas que giravam em torno, por exemplo, dos encontros e desencontros das personagens das radionovelas bem como era evidenciada no carinho inocente dos fãs do rádio com seus produtores:

A gente discutia sobre a vida das personagens. Era uma coisa meio lúdica, inocente, sem muito propósito. A gente falava de Mariângela que não via a luz do sol e que se pensava que era porque o marido não deixava mas era porque ela era cega, irremediavelmente cega. Eram as tragédias das novelas do rádio que estavam nas nossas preocupações e nas nossas conversas. (Neide Garcia, 62, professora aposentada)

As pessoas naquele tempo gostavam de sentar nas calçadas para discutir como seria o destino dos personagens. Vivia-se numa sociedade inocente, menos polemizada, com temas leves. (Karla Peixoto, 65, radioatriz).

E a gente escutava as pessoas que queriam nos conhecer e ficavam esperando do lado de fora do rádio, e iam levando flores, presentes. Você recebia de tudo, de pássaro, de frango, peru, frutas, toalhas. Incrível, eles faziam de tudo para agradar ao artista. (Ivone Meyre, 64, radioatriz).

Sem propósitos objetivos nem resultados exteriores, essa interação foi, entre outras coisas, o sucesso de determinadas práticas que chegavam à Cidade impulsionadas pelo veículo. A freqüência ao cinema sofisticava a moda e os costumes, o consumo do rock e dos estereótipos dos componentes das bandas (cabelos compridos, sapatos e vestimentas diferenciadas) foram incorporados como símbolos de uma juventude 
“moderna” estimulados pela leitura de revistas que lançavam um novo bem cultural: as fotonovelas.

Aqui havia a Folha do Rádio que dava a notícia das pessoas, tinha foto também pra poder o ouvinte acompanhar, tinha concurso, a melhor atriz, o melhor ator, o melhor coadjuvante, a pessoa comprava a revista e tinha os folhetinhos, uma folhinha com pedacinho para destacar e aí era um voto. (Glice Sales, 63 , radioatriz).

Eu escrevia para os programas, pedia músicas, dava vários nomes falsos, porque a gente mandava várias cartas para serem sorteadas para ganhar revistas, como Querida e Capricho. A Querida era uma revista muito boa de contos. A Capricho era de fotonovela. A Querida era uma revista de reportagens e contos. O tamanho delas era pequeno, mas bem grossas. Hoje em dia, eu vi numa dessas bancas de revista a Capricho, uma revista deste tamanhinho. Antes era uma revista grande e boa que vinha com fotonovela, reportagens, histórias, fofocas de rádio, que naquela época eram das cantoras e dos cantores.( Neide, 62, professora aposentada).

Entrementes a freqüência ao cinema não era compartilhada por todos os fortalezenses, mas somente por aqueles cuja posição social lhes permitiam ter acesso a este equipamento cultural. Até mesmo as idas aos programas de auditório, apesar de terem audiência cativa em todas as classes sociais eram um apanágio de classe: somente àqueles com determinado capital quer intelectual quer financeiro freqüentavam os auditórios das estações de rádio.

Eu me lembro que nos pontos de encontro sempre se encontrava as mesmas pessoas. No cinema era a classe elegante que freqüentava, vestiase paletó e gravata. Mas nos programas de auditório era a classe média que ocupava o espaço. Os populares não apareciam. Os programas de auditório eram muito bem freqüentados (Diatahy, Bezerra, 71, professor universitário aposentado).

Os cantores locais apareciam nos programas de auditório. Os programas de auditório eram muito bem freqüentados, lá se encontrava toda a sociedade fortalezense, não ia gente pequena não, era a classe média que estava ali. (Glice Sales, 63, radioatriz).

As pessoas iam sim (aos programas de auditório), mas não era pra todo mundo. (Karla Peixoto, 65, radioatriz). 
Em conseqüência disso, as condições e os resultados desse processo eram a reunião de indivíduos em eventos domésticos ou sociais que se abastecia não só dos conteúdos mas também das novas práticas sociais que se estabeleciam a partir das informações radiofônicas e que ocorriam tanto no espaço público como no privado. Nas casas de família, adquiria-se o hábito de receber amigos e parentes ao som das vitrolas que repercutiam os sucessos do momento. Nos clubes, espaços por excelência de interação das elites, as grandes orquestras reproduziam os mesmos sucessos, entretanto de forma mais glamourizada.

Por exemplo, à noite, às nove horas da noite, tinha o "Bazar da Música”, era o único programa de discos para dançar. Tocava duas horas de programa, que as pessoas aproveitavam para ter festinhas em casa, se chamava "Bazar da Música”. Os bailes aconteciam no sábado ou domingo, não lembro bem, mas sei que eram uma vez por semana. (Nirez, 71, funcionário público aposentado).

O caráter destas relações era determinado por uma amabilidade, um refinamento, uma cordialidade que se absorvia das conversas advindas dos conteúdos radiofônicos que funcionavam como fonte de alimentação de desejos de inserção num mundo que se revelava bem maior do que as fronteiras da província e como fomentos de um novo status social. A possibilidade de participar de gincanas, de entrar em sorteios, de fazer parte dos gracejos do apresentador criava novos laços de visibilidade social ${ }^{14}$. Quem conseguisse entrar no circuito midiático do rádio adquiria uma aura de diferenciação social (Barbero, 1988). Era um novo status que surgia por intermédio do novo meio.

Tinha um programa de contato com os ouvintes que era "mensagens sonoras". Era quase uma hora de rádio. As pessoas aniversariavam e os outros queriam homenagear através de músicas no rádio. Aquilo ali dava status, fazia bem. Então saía música de todo jeito, música erudita e música popular. (Karla Peixoto, 65, radioatriz).

Estas sociabilidades que se formavam calcadas em um imaginário atrelado aos ideais europeus e norte-americanos de desenvolvimento ${ }^{15}$, existentes por si sós na cultura local, pois, independentes do veículo, encontravam no rádio um mediador eficaz para a intensificação de sentimentos de pertença ao mundo de além mar, já historicamente sedimentada, bem como para a consolidação de novas fronteiras sociais. 
O rádio foi fundamental para impulsionar as mudanças dos hábitos da população; as indústrias, as empresas de produção de bens, tais como alimento, vestuário, cosméticos, entre outros, descobriram no veículo seu potencial de propagação e convencimento e o poder de criar necessidades de uso de novos produtos, sobretudo por meio das propagandas. A associação entre esse modelo de produção em série que se instaurava, nas indústrias e nas empresas de prestação de serviços caracterizavam uma nova sociedade: a sociedade de consumo.

Os conteúdos vindos dos grandes centros urbanos, nacionais ou internacionais alimentavam as conversas que agora saíam dos tons domésticos e adquiriam uma sofisticação pertencente ao “mundo civilizado". Neste mundo, mediado pelo rádio, as artes encontravam agora mais prestígio e conferiam status diferenciado às elites fortalezenses. Era chique falar sobre uma peça produzida em Paris, ainda que eles próprios jamais tivessem tido acesso a um bem cultural deste nível. Era elegante freqüentar saraus promovidos por pessoas da elite e nestes comentar a última moda no Rio de Janeiro que as cantoras de rádio exibiam nas suas apresentações assim como o mais recente lançamento de Hollywood que não só não era exatamente o mais recente como, muitas vezes, sequer chegava aos nossos ares.

Criava-se, portanto, uma sociabilidade que denominamos de marginalizadora. Eram ainda poucos os convidados para participar deste tipo de colóquio informal, uma vez, que mesmo que o rádio veiculasse conteúdos aparentemente disponíveis a todos, os códigos que construíam esses conteúdos eram interditados à maior parte da população fortalezense que, semi-analfabeta nos interstícios de uma cultura dita mais erudita, pouco se aventurava além dos conteúdos dos programas de auditório e das radionovelas.

Mas, quando o golpe militar entra no contexto da cidade de Fortaleza, essa sociabilidade se modifica. O rádio, na década de 60, ainda era um grande veículo. A televisão estava dando seus primeiros passos, e a maior parte dos eventos importantes do País ainda eram acompanhados pelo rádio.

Na década de 60, o rádio ainda era um grande veiculo, as radioatrizes $e$ cantoras do rádio eram conhecidíssimas. Em 1962, a copa foi toda pelo rádio. Vc imaginava o locutor dizendo tudo. A nossa cultura era a da oralidade, tínhamos a liberdade de imaginar porque era o olho interior que criava. (Diatahy Menezes, 71, professor aposentado). 
Quanto aos noticiosos, eram esses os que mais sofriam com as novas exigências do governo militar. Na programação local, os noticiários possuíam desde a década anterior um lugar de destaque que perdurara na década seguinte. Sua importância para a popularidade do rádio era inegável, tornando-se, portanto, presença constante na grade de programação.

E tinha o noticiário que era importante, sempre a notícia foi um lugar de destaque no rádio. Tinha pela manhã, ao meio dia, tinha o noticiário relâmpago que de repente invadia a programação. (Glice Sales, 63, radioatriz).

Entrementes, a repressão do governo militar às redações das estações ocupava lugar diferenciado no imaginário tanto de produtores como de receptores. As notícias continuam a dar ênfase a uma sociedade de consumo, mas agora, bem mais infraestruturada. Os ideais nacionalistas se perpetuavam, embalados, agora, pela sofisticação das propagandas governamentais (Figueiredo, 1998). Mas, já não proporcionavam mais interações descompromissadas e despreocupadas como as visíveis na década anterior.

A censura vai ocasionar mudanças nas redações assim como o fez na sociedade global. As radionovelas entram em decadência. As narrações melodramáticas não combinam mais com as exigências da nova década. Os programas de auditório, líderes de audiência das programações das emissoras, migram do rádio para a televisão.

Quando a TV Ceará abriu, no canal 2, pegou um elenco que vinha do rádio já amadurecido, já com cultura. (Glice Sales, 63, radioatriz).

E aí já tava o radioteatro morrendo porque o pessoal já estava empolgadíssimo com a novidade, a televisão, e aí foi morrendo no rádio, tanto que acabou. ( Karla Peixoto, 65, radioatriz).

Mas, se para alguns, o regime de exceção atuou de forma "leve” no rádio cearense, para outros, as ordens de censura ditadas pelos militares tiveram um impacto intenso na forma de produzir notícias em Fortaleza, criando uma sociabilidade que, se dantes alimentava os sonhos de felicidade, agora se fechava num silêncio temeroso e opressor. Qualquer pessoa, estudante, médico, professor, jornalista que expressasse uma opinião diferente da ordem dominante era taxado de comunista, perseguido e preso para prestar contas ao regime. Muitos foram aprisionados e espancados com brutalidade por 
todo o País. As sociabilidades da década anterior atrelada às novidades e ao glamour dos produtos advindos das novas tecnologias foram recalcadas pelos agentes do SNI (Serviço Nacional de Inteligência) ou pelos chamados “dedos duro” (os delatores) que podiam estar por toda parte.

Dessa forma, instaura-se o medo a ponto de conversas serem evitadas em salas de aula, em corredores, nas cantinas, praças ou qualquer logradouro público. Não que houvesse um militar em cada esquina é que o regime de exceção agia com tal truculência que as pessoas evitavam estar em grupos. As reuniões festivas que se faziam em torno do rádio nas casas, nos bares ou nas calçadas foram evitadas. O medo apoderou-se também do espaço privado. As pessoas temiam convidar amigos para suas casas. Um entra e sai de indivíduos não era bem visto pelo regime e, quando acontecia, levantava suspeitas.

Dessa forma, o regime foi impeditivo até do estabelecimento de amizades. O rádio, assim como os outros meios de comunicação, estava sob forte censura. Desobedecer ao regime teria como punição a cadeia para os apresentadores e responsáveis pela estação e o fechamento da emissora como aconteceu com a Rádio Dragão do Mar, em Fortaleza. Estas múltiplas realidades são bem mostradas nos depoimentos que se seguem:

Eram tempos mais fáceis até porque o nosso líder maior, Assis Chateaubriand, ele não se vinculava a ninguém e nós estávamos ali, navegando por sobre o mar de interesses, mas aquilo não dizia diretamente a nós, artistas. (Karla Peixoto,65, radioatriz)

O governo começou a dar em cima, aquele negócio todo dos militares. Eles fecharam a rádio Dragão do Mar e saiu todo mundo, ai nós fomos indenizados e depois eu voltei como locutora. Aí eu procurei um general que estava tomando conta da rádio e ele também gostou da minha voz, mas não tinha mais novelas e eu fiz os programas diários. (Glauria Faria, 64 , radioatriz).

O rádio teatro não foi tão atingido, a briga era mesmo com os locutores. Eu vi a prisão do Dr. Alberto Studart, do hospital dos tuberculosos. Jogavam as pessoas no caminhão, as famílias choravam. Foram coisas terríveis, o que você fazia naquela época, o terror era tão grande que você se calava. Não existia revolta, essa coisa de ir pras rua e brigar, os artistas se calavam. E ficavam sofrendo calados. A gente atravessava aquele período de dor e sofrimento mas calados, sem protestar 
publicamente. Os que protestavam viam os resultados. Eram prisões com sofrimento e deportação, jogavam pra longe do Brasil, você temia ate pelos familiares. Era muito difícil, muito diferente. (Glauria Faria, 64, radioatriz).

Este foi, em linhas gerais, o cenário no qual as sociabilidades mediadas pelo rádio deram-se em Fortaleza, no período selecionado. Obviamente, como pôde ser observado durante esta pesquisa, mudanças importantes foram estabelecidas entre uma década e outra. Se o golpe militar de 64 garante a uma emergente classe média a continuidade de um novo status social e apregoa para as classes populares a possibilidade de entrada na sociedade de consumo, o posterior endurecimento da política do novo governo que encontra seu ápice no AI-5 vai reconfigurar esse panorama, em especial, no que diz respeito ao papel do rádio neste cenário.

No rádio, o tom dos noticiosos se modifica. Enquanto os noticiários se tornavam mais “pesados”, na década de 60, contrariando a "leveza”, típica de uma cultura fundada nas relações de compadrio, as populares radionovelas entravam em decadência. Lentamente, foram sendo substituídas no imaginário do fortalezense pelo teleteatro e posteriormente pelas telenovelas. O rádio, durante toda a década seguinte, sofreu uma série de adaptações a fim de sobreviver neste cenário.

As notícias continuam a enaltecer a sociedade de consumo e os ideais nacionalistas, mas já não havia mais a nuance alegre, descompromissada e despreocupada da década anterior. A censura modifica o clima nas redações assim como na sociedade maior. As radionovelas, com seus ardentes amores, e suas inocentes heroínas não combinam mais com as exigências dos novos tempos. Os programas de auditório, líderes de audiência das programações das emissoras, migram do rádio para a recém-lançada televisão.

O mundo deixa de chegar em sons e passa a vir em imagens para a população fortalezense. A estrutura de produção angariada pelo rádio em duas décadas é absorvida pela televisão e o rádio, nos anos seguintes, para sobreviver, entra em um processo de reconfiguração, modificando as interações que estabelece com seus ouvintes. 


\section{NOTAS}

${ }^{1}$. Graduada em Comunicação Social. Mestre e Doutora em Sociologia. Professora Adjunto IX da Universidade Estadual do Ceará - UECE.

2. Graduada em Comunicação Social. Mestre e Doutora em Sociologia. Professora Titular da Universidade de Fortaleza- Unifor.

3. Entendemos sociabilidade na mesma acepção de Simmel (1983) como um processo social fundante baseado em formas de interação plurais e variadas, permeadas pela aproximação e pela separação, pelo consenso e pelo conflito, pela competição, pela dominação e pela subordinação. 4. As reflexões sobre o impacto do rádio nos anos 50, em Fortaleza, capital do Ceará, já foram realizadas em um trabalho nosso anterior. (Andrade e Silva, 2006). Este artigo se constitui, portanto, uma continuidade de pesquisa. Ressaltamos que no trabalho anterior a ênfase da pesquisa não estava vinculada à uma questão de construção de sociabilidades, mas sim, de diálogos entre gerações e classes sociais distintas e não abarcava ainda a década de 60 na qual a ditadura militar encontrou um espaço significativo de atuação.

5. Para Schutz, o mundo é interpretado a luz de categorias e construtos do senso comum que são largamente sociais na sua origem (Heritage, 1999). Esses elementos são os recursos que os indivíduos utilizam para compreender e serem compreendidos nas suas ações do cotidiano. A realidade é fruto dessa contínua atividade de interpretação dos sentidos das ações que são empreendidas no dia-a-dia.

6. Entrementes, realçamos que os homens, e aqui, incluem-se os sujeitos sociais desta pesquisa, não vivem em sociedade apenas reproduzindo ações de modo a se adaptarem à conjuntura no qual estão inseridos. Os produtores e receptores entrevistados neste estudo construíram seu próprio recorte de ação, de pensamento e de interação, tendo um ponto em comum, dentre outros, uma comunicação midiática, mais especificamente, radiofônica. Acreditamos, junto com Garfinkel (1984) que o indivíduo não é um “tolo social”, regido apenas por coerções externas. Os contextos nos quais as normas se formam estão presentes nas análises que os sujeitos sociais fazem de seus atos e formas de pensar. Estas análises tanto são influenciadas pelos contextos sociais como os influenciam, assim, os sujeitos agem por sobre esses contextos interpretandoos, ajustando-os e modificando-os eventualmente (Votre e Figueiredo, 2003).

7. Neste sentido, ressaltamos que os símbolos utilizados para nossa comunicação não se encontram estabelecidos em conjuntos de regras e normas de comunicação preexistentes, mas são construídos e produzidos por processos de interpretação. Aqui se funda a passagem de um paradigma normativo (parsoniano) para um interpretativo (etnometodológico). Em outras palavras, os indivíduos produzem os símbolos e códigos utilizados para estabelecer uma comunicação inteligível, interpretando as ações daqueles com quem estabelecem relação. Tais símbolos são reinventados e adaptados a cada novo encontro (Guesser, 2003).

8. Na concepção de Heller (1989), o homem já nasce inserido na cotidianeidade. A vida dele é a vida cotidiana em sua mais total plenitude. Não há aquele que se diga não participar de uma vida cotidiana, pois, é nela que o homem coloca-se por inteiro, sentimentalmente, emocionalmente e ideologicamente, com suas idéias, capacidades, sentidos e habilidades.

9. Este trabalho é parte de uma pesquisa sobre a radiodifusão cearense tomando como suporte a memória dos velhos radialistas, radioatores, radioatrizes, técnicos, empresários, locutores que fizeram sua história e se realiza junto com os estudantes de Jornalismo e Ciências Sociais da Universidade de Fortaleza e da Universidade Estadual do Ceará, em Fortaleza, capital do Ceará. 10. A memória é, de acordo com Silverstone (2002) o que se faz recordar pelo testemunho oral e pelo discurso compartilhável. É onde os fios privados do passado se entrelaçam no tecido público, oferecendo-nos uma visão alternativa às versões oficiais da academia e dos arquivos.

11. Rapazes tidos como assediadores sexuais das inocentes jovens, abordadas na saída do colégio ou na parada dos ônibus, no Centro da cidade e em seus arredores. Criou-se lenda a respeito de famosos rabos de burro em Fortaleza na década de 60. A fama e o temor espalhados serviam aos pais de família para manterem suas filhas no recesso do lar, resguardadas das investidas do nefasto malfeitor. 
12. Na esfera política, passamos da era Vargas e entramos na era Kubitschek. Nestas ondas de modernização, era preciso ousar, e JK ousou ao anunciar seu programa de governo - 50 anos de progresso em 5 anos de ação política. Esse ideal desenvolvimentista foi consolidado num conjunto de objetivos a serem concretizados em vários setores da economia. Mas, a principal mudança de seu governo nos trâmites históricos foi a construção de Brasília e a transferência da capital federal para o novo território (Singer, 1981). Neste sentido, a idéia do desenvolvimento estava baseada na vida urbana industrializada. Segundo Figueiredo (1998), à cidade e à indústria cabia um papel civilizador. Esse papel aparecia em vários anúncios da época como o da Eletrobrás que preconizava "energia para as cidades, desenvolvimento para o interior".

13. Se a sociologia implica um conhecimento das formas de vida (Simmel, 1983) que organizam as relações sociais, com suas interações institucionais (a macro sociologia) e não institucionais (a micro sociologia), os fenômenos desta micro sociologia estão ligados a aspectos culturais que dependem das interações que estabelecem com os primeiros, aqueles oriundos da macro sociologia. Entre os fenômenos dessa macro sociologia está a difusão da mídia nas sociedades contemporâneas; entre os da micro, as interações que essa difusão ocasiona no espaço das relações intersubjetivas dos indivíduos, isto é, no da comunidade vivida dos agentes sociais.

14. Ver mais sobre os mecanismo de construção da visibilidade social em Goffman (2006).

15. As idéias de um Brasil Moderno sempre estiveram vinculados no decorrer de nossa história aos contextos europeus ou norte-americanos de desenvolvimento, o que levou muito de nós, a pensarmos que nossa colonização não foi somente econômica, mas cultural e política (Ianni,1996).

\section{Bibliografia}

ANDRADE, R.M.B; SILVA, E.H. O rádio dos anos cinqüenta no Nordeste do Brasil: produtores e ouvintes em perspectiva IN: IV Encontro Nacional de História da Mídia. São Luiz: 2006.

BARBERO, J. M. De los medios a las mediaciones- comunicacion, cultura e hegemonia. México, Gustavo Gili, 1988.

CARONE, E. A Quarta República (1945-1964). São Paulo: Difel, 1980.

FIGUEIREDO, A. C. M. "Liberdade é uma calça velha e desbotada". São Paulo: Hucitec, 1998.

GARFINKEL, Harold. Studies in Ethnomethodology. Cambridge England: Polity Press, 1984. GOFFMAN, E. A representação do eu na vida cotidiana. Rio de Janeiro: Vozes, 2006.

GUESSER , Adalto H. A etnometodologia e a análise da conversação e da fala In: Revista Eletrônica dos Pós-Graduandos em Sociologia Política da UFSC Vol. $1 \mathrm{n}^{0} 1$ (1), agostodezembro/2003, p. 149-168, acessado em www.emtese.ufsc.br em 03/04/2007.

HELLER, A. O cotidiano e a história, Rio de Janeiro, Paz e Terra, 1989.

HERITAGE, John C. Etnometodologia. In GIDDENS, Anthony e TURNER, Jonathan (org.). Teoria Social Hoje. São Paulo: UNESP, 1999.

HOLANDA, S. B. Raízes do Brasil. Rio de Janeiro. Companhia das Letras, 1997.

IANNI, O. A idéia do Brasil Moderno. São Paulo: Brasiliense, 1996.

VOTRE, Sebastião Josué; FIGUEIREDO, Carlos. Etnometodologia e educação Física. Disponível em www.geocities.com/Athens/Styx/9231/etnometodologia.html, acessado em 15/04/2007.

SILVERSTONE, R. Por que estudar a mídia?. São Paulo, Loyola, 2002.

SIMMEL, G. Sociologia, Madri, Edições Castillas, 1983.

SINGER, P. Interpretação do Brasil: uma experiência histórica de desenvolvimento. IN: Fausto, B. (org). O Brasil Republicano III: economia e cultura (1930-1964). São Paulo: Difel, 1981. 